\title{
pH do meio de cultivo e crescimento de plântulas de ginseng brasileiro cultivadas in vitro
}

\author{
Culture medium pH and growth of brazilian ginseng in vitro cultured plantlets
}

\author{
Fernando Teixeira Nicoloso ${ }^{\mathrm{I}}$ Gregori da Encarnação Ferrão ${ }^{\mathrm{II}}$ Gabriel Y Castro ${ }^{\mathrm{III}}$
}

\begin{abstract}
O presente trabalho objetivou avaliar o efeito do $\mathrm{pH}$ do meio de cultivo sobre alguns parâmetros de crescimento da Pfaffia glomerata (Spreng.) Pedersen cultivada in vitro, bem como checar se o crescimento dos explantes altera o $\mathrm{pH}$ do meio ao longo do período de cultivo. Foram testados quatro tratamentos constituídos de distintos valores de $\mathrm{pH}(3,7 ; 5,0$; 6,0 e 7,5) do meio de cultivo. O pH do meio de cultivo foi ajustado antes da inclusão do agar $\left(6 \mathrm{~g} \mathrm{~L}^{-1}-\right.$ Merck) e da autoclavagem. Como fonte de explantes foram utilizadas segmentos nodais de plantas previamente estabelecidas in vitro em meio MS. Dos nove aos 15 dias após a inoculação (DAI) dos segmentos nodais, verificou-se maior número de raízes em pH 6,0 e o menor no $\mathrm{pH}$ 7,5. Aos 35 DAI, o comprimento da maior brotação e o número total de segmentos nodais por planta foram maiores em torno de $\mathrm{pH}$ 6,0. Aos $35 \mathrm{DAI}$, observou-se menor crescimento em biomassa de raízes em $\mathrm{pH}$ 3,7. Já a parte aérea apresentou menor biomassa em $\mathrm{pH}$ 7,5. Aos 35 DAI, a produção de matéria fresca e seca total da plântula foi maior em $p H$ próximo a 6,0. Concluiu-se que valores de $\mathrm{pH}$ do meio de cultivo próximos a 6,0, ajustados antes da autoclavagem, são ideais para o crescimento da $\boldsymbol{P}$. glomerata cultivada in vitro. Também se verificou que o crescimento da plântula modificou significativamente o $\mathrm{pH}$ do meio de cultivo.
\end{abstract}

Palavras-chave: Pfaffia glomerata, Amaranthaceae, cultura de tecidos, cultivo in vitro.

\section{ABSTRACT}

The present research aimed to evaluate the effect of culture medium $\mathrm{pH}$ on some growth parameter of Pfaffia glomerata (Spreng.) Pedersen in vitro cultured plantlets, as well as to check whether the explant's growth alters the culture medium $\mathrm{pH}$. Four treatments consisted of different values (3.7; 5.0; 6.0 and 7.5) of culture medium $p H$ were tested. The culture medium $\mathrm{pH}$ was adjusted prior to the addition of agar $\left(6 \mathrm{~g} \mathrm{~L}^{-1}\right.$ - Merck) and autoclaving. Nodal segments from asseptic plants grown in MS medium were used as explants. From 9 to 15 days after inoculation (DAI) of nodal segments, the higher number of roots was obtained at $p H$ 6.0, and the lower at $p H$ 7.5. At 35 DAI, both length of the higher sprout and total number of nodal segments per plantlet were greater at about $p H$ 6.0. At 35 DAI, roots biomass was lower at $p H$ 3.7. On the other hand, shoots biomass was lower at $p H$ 7.5. Fresh and dry matter of the whole plantlet was greater at $\mathrm{pH}$ around 6.0. In conclusion, values of culture medium $\mathrm{pH}$ near to 6.0, adjusted prior to autoclaving, are ideal for the growth of P. glomerata in vitro cultured plantlets. Moreover, the in vitro growth of plantlet modified significantly the culture medium $\mathrm{pH}$.

Key words: Pfaffia glomerata, Amaranthaceae, tissue culture, in vitro culture.

A Pfaffia glomerata (Spreng.) Pedersen (Amaranthaceae) é uma espécie de grande interesse comercial devido sua ampla utilização na indústria de fitoterápicos e fitocosméticos. Em razão disso, tem ocorrido uma intensa exploração predatória das reservas naturais desta espécie, justificando a elaboração de planos de manejo ou projetos de cultivo (MONTANARI JÚNIOR, 1999).

A maioria das culturas in vitro de tecidos vegetais tolera uma ampla faixa de $\mathrm{pH}$ do meio de cultivo,

'Departamento de Biologia, Universidade Federal de Santa Maria (UFSM), Campus Universitário, Camobi, 97105-900, Santa Maria, RS, Brasil. E-mail: ftnicoloso@yahoo.com. Autor para correspondência.

"Programa de Pós-graduação em Fisiologia e Bioquímica de Plantas, Universidade de São Paulo (USP), Escola Superior de Agricultura Luiz de Queiroz (ESALQ), Piracicaba, SP, Brasil.

IIIPrograma de Pós-graduação em Agronomia, UFSM, Santa Maria, RS, Brasil. E-mail: gabrycastro@gmail.com. 
o qual geralmente é ajustado antes da autoclavagem. Além dos fatores físicos que influenciam as alterações do $\mathrm{pH}$ do meio de cultivo in vitro, é conhecido o fato que a presença de tecidos vegetais também pode alterar o mesmo. SKIRVIN et al. (1986) verificaram que o crescimento de calos de Cucumis melo alterou significativamente o $\mathrm{pH}$ do meio de cultivo já nas primeiras 48 horas de cultivo.

Geralmente, os meios de cultivo de tecidos vegetais têm baixa capacidade de tamponamento (LEIFERT et al., 1995) e, por isso, algumas espécies são capazes de ajustar o pH do meio para valores entre 3,7 e 6,2 durante o período de crescimento da planta, independentemente do $\mathrm{pH}$ inicial do meio (LEIFERT et al., 1992). Diferenças marcantes foram encontradas entre sete espécies vegetais (Choisya ternata, Daphne blagayana, Delphinium "11", Hemerocallis "Stella d'Oro”, Hosta "Halcyon”, Íris germânica, e Photinia fraseri) quanto ao requerimento de $\mathrm{pH}$ para obter ótimas taxas de crescimento e enraizamento, as quais foram induzidas pelas próprias plantas (LEIFERT et al., 1992). Portanto, as interações entre o desempenho do crescimento e as variações do $\mathrm{pH}$ do meio de cultivo parecem ser dependentes do genótipo vegetal.

O presente trabalho teve como objetivo avaliar o efeito da variação do $\mathrm{pH}$ do meio de cultivo sobre alguns parâmetros de crescimento de plântulas de Pfaffia glomerata cultivada in vitro, bem como checar se o crescimento dos explantes altera o pH do meio ao longo do período de cultivo.

Como fonte de explantes, foram utilizados segmentos nodais (1,0cm de comprimento e sem folhas) de plantas de $\boldsymbol{P}$ faffia glomerata cultivadas in vitro em meio de cultivo MS (MURASHIGE \& SKOOG, 1962), acrescido de $30 \mathrm{~g} \mathrm{~L}^{-1}$ de sacarose, $100 \mathrm{mg} \mathrm{L}^{-1}$ de mioinositol, $6 \mathrm{~g} \mathrm{~L}^{-1}$ de agar (Merck) e sem fitoreguladores, conforme metodologia descrita por NICOLOSO et al. (2001).

Foram testados quatro tratamentos constituídos de distintos valores de $\mathrm{pH}$ (3,7; 5,0; 6,0 e $7,5)$ do meio de cultivo. $\mathrm{O} \mathrm{pH}$ do meio de cultivo foi ajustado com $\mathrm{HCl}$ ou $\mathrm{NaOH}(0,1 \mathrm{M})$ antes da inclusão do agar e da autoclavagem $\left(1 \mathrm{~atm}, 120^{\circ} \mathrm{C}, 15 \mathrm{~min}\right)$. Após a inoculação, os explantes foram cultivados em sala de crescimento com temperatura de $25 \pm 2^{\circ} \mathrm{C}$, fotoperíodo de $16 \mathrm{~h}$ e intensidade luminosa de $35 \mu \mathrm{mol} \mathrm{m} \mathrm{m}^{-2} \mathrm{~s}^{-1}$ fornecida por lâmpadas fluorescentes branca-frias.

O delineamento experimental foi o inteiramente ao acaso com 85 repetições. A parcela experimental consistiu de um tubo de ensaio $(15 \mathrm{~cm}$ de altura x 2,5cm de $\phi$, volume interno $147,26 \mathrm{~cm}^{3}$ ) contendo $10 \mathrm{~mL}$ de meio de cultivo MS, modificado nos valores de $\mathrm{pH}$, com um segmento nodal como explante.
As avaliações do crescimento das plântulas foram realizadas em diferentes períodos após a inoculação dos explantes. De 35 repetições, aos seis, oito, nove, 10, 11, 12 e 15 dias após a inoculação (DAI), foi avaliado o número de raízes emitidos por plântula. Dessas mesmas unidades experimentais, aos 35 DAI, foram avaliados a altura da maior brotação, o número total de segmentos nodais por plântula e a matéria fresca e seca das raízes, da parte aérea e do total das plântulas. $\mathrm{O}$ pH dos meios de cultivo foi avaliado nos tempos zero, três, seis, oito, 12, 15, 20, 25, 30 e 35 DAI, utilizandose cinco repetições em cada tempo.

Os dados experimentais foram submetidos à análise de variância. O comportamento individual dos parâmetros de crescimento das plantas foi avaliado por regressões em nível de 5\% de probabilidade de erro. Para o número de raízes por planta, foi realizada a análise por regressões polinomiais para o fator épocas de avaliação e comparação de médias (Teste Tukey) para o fator tratamentos de $\mathrm{pH}$, em nível de $5 \%$ de probabilidade de erro.

O número de raízes por plântula aumentou ao longo do período de cultivo indistintamente do tratamento, apresentando resposta cúbica aos valores de $\mathrm{pH}$ 3,7, 5,0 e 6,0, bem como resposta quadrática ao $\mathrm{pH}$ 7,5 (Figura 1A). Apesar desse comportamento, o número de raízes somente começou a diferir, em função do $\mathrm{pH}$ do meio de cultivo, a partir dos nove dias após a inoculação (DAI), sendo que neste momento o melhor tratamento foi o de $\mathrm{pH}$ 6,0. Aos $10 \mathrm{DAI}$, todos os tratamentos diferiram entre si, apresentando o pior resultado em pH 7,5. Aos 11, 12 e 15 DAI, o maior número de raízes por explante foi obtido em $\mathrm{pH}$ 6,0 e o menor no $\mathrm{pH}$ 7,5.

Aos 35 DAI, o comprimento da maior brotação (Figura 1B) e o número total de segmentos nodais por plântula (Figura 1C) apresentaram resposta cúbica à variação do $\mathrm{pH}$, com máxima resposta em torno de pH 6,0. Para estes parâmetros, salienta-se que a elevação do pH para 7,5 reduziu o crescimento.

A biomassa fresca e seca dos órgãos da plântula respondeu distintamente à variação do $\mathrm{pH}$ aos 35 DAI. Foi observado menor crescimento em matéria fresca (Figura 1D) e seca (Figura 1E) de raízes em $\mathrm{pH}$ 3,7. Já a parte aérea apresentou menor matéria seca em pH 7,5 (Figura 1E). Aos 35 DAI, momento em que as plantas atingiram o máximo comprimento da maior brotação (Figura 1B) e o número total de segmentos nodais por plântula (Figura 1C), a produção de matéria fresca (Figura 1D) e seca (Figura 1E) total da plântula foi máxima em $\mathrm{pH}$ próximo a 6,0. Diferentemente ao encontrado para outros parâmetros de crescimento, salienta-se que tanto a redução do $\mathrm{pH}$ para 3,7 como a 

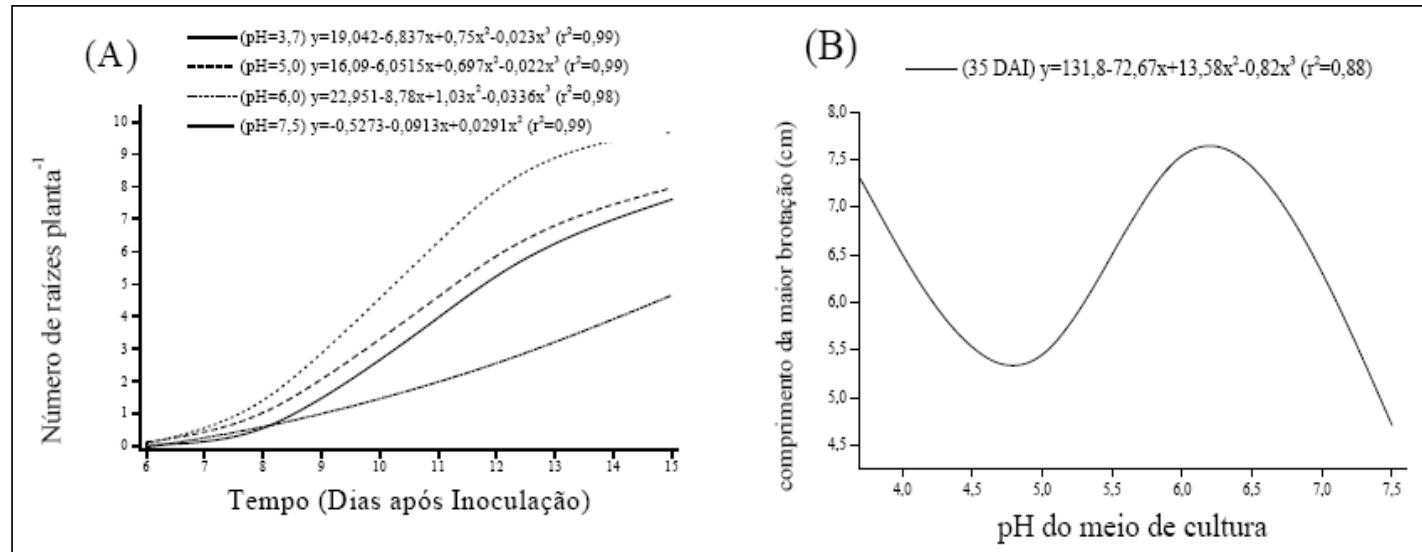

(C)

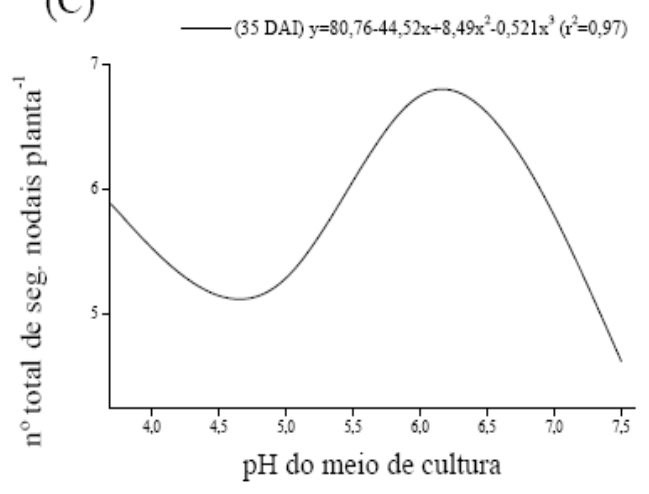

(D) - (raiz) $\mathrm{y}=3,84-2,21 \mathrm{x}+0,4255 \mathrm{x}^{2}-0,026 \mathrm{x}^{3}\left(\mathrm{r}^{2}=0,99\right)$

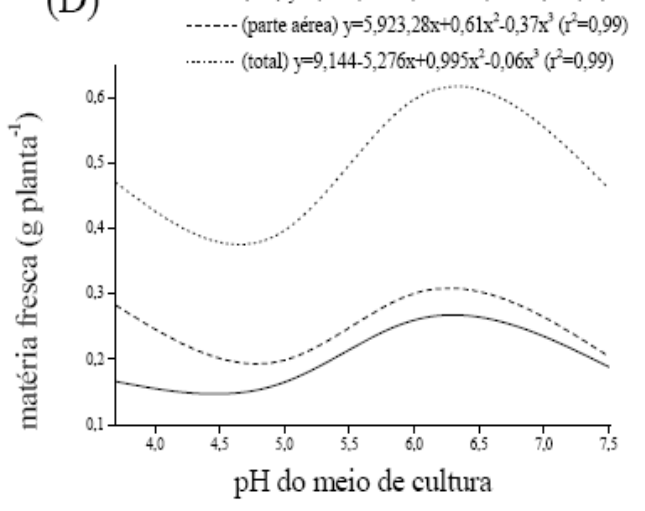

(E) - (raiz) $y=0,195-0,11 x+0,022 x^{2}-0,0013 x^{3}\left(x^{2}=0,99\right)$

(F)
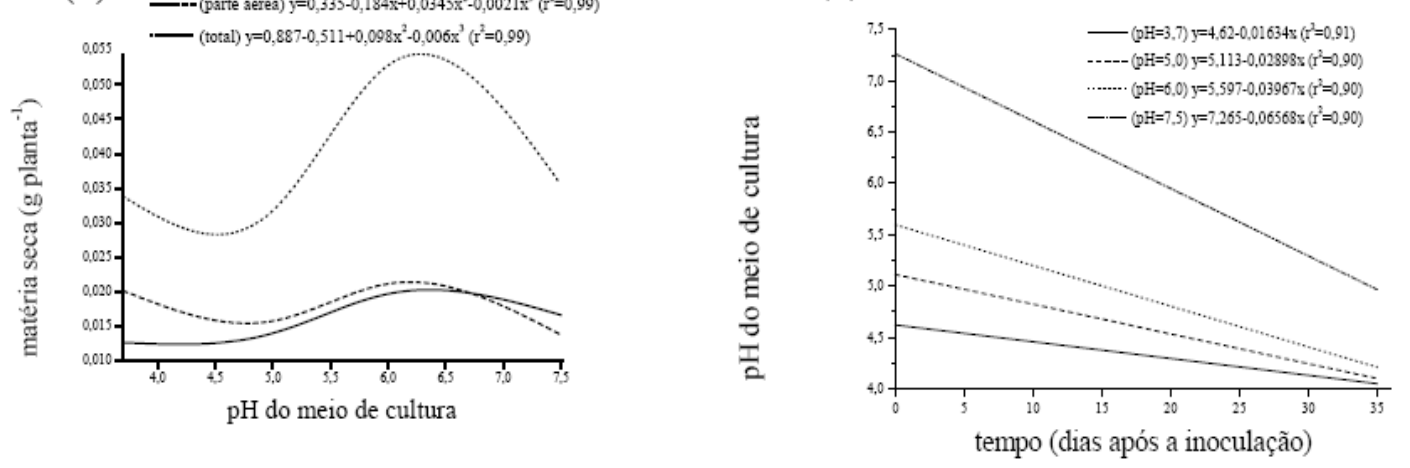

Figura 1 - Número de raízes por explante entre 6 e 15 dias após a inoculação (A), comprimento da maior brotação (B), número total de segmentos nodais (C), matéria fresca (D) e matéria seca (E) por plântula de Pfaffia glomerata cultivada in vitro sob diferentes valores de $\mathrm{pH}$ do meio de cultivo aos 35 dias após a inoculação (DAI), bem como $\mathrm{pH}$ do meio de cultivo ao longo do período experimental.

elevação deste para 7,5 não foram benéficas à produção de biomassa total da planta (Figuras 1D e 1E). Essa influência negativa, provavelmente, se deve às modificações na disponibilidade dos nutrientes no substrato, fato largamente conhecido nos cultivos em solo (MARSCHNER, 1995).

O padrão de crescimento baseado na produção de biomassa, no comprimento da brotação e 
no número de segmentos nodais, observado no tratamento de $\mathrm{pH}$ 6,0, é semelhante àqueles relatados para $\boldsymbol{P}$. glomerata por NICOLOSO et al. (2001), que utilizaram meio de cultivo MS com $\mathrm{pH}$ ajustado para 5,8 . Portanto, fica demonstrado que o ajuste do $\mathrm{pH}$ do meio de cultivo para valores próximos a 6,0, antes da autoclavagem, proporciona a melhor condição para o crescimento dessa espécie quando multiplicada in vitro.

Ao longo do período experimental, foi observado que os meios de cultivo sofreram alterações no pH (Figura 1F). Portanto, a presença de plântulas, indistintamente do valor original do $\mathrm{pH}$ do meio de cultivo, provocou significativa diminuição do $\mathrm{pH}$, sendo que aos 35 DAI foram observadas diferenças de 0,29, 0,41, 0,83 e 1,51 unidades de $\mathrm{pH}$, respectivamente para os tratamentos de pH 3,7, 5,0, 6,0 e 7,5, em relação ao valor original (Figura 1F). SKIRVIN et al. (1986) também observaram que a direção e a quantidade da variação do $\mathrm{pH}$ (aumento ou decréscimo) foram significativamente correlacionadas com o pH original do meio de cultivo.

Considerando-se que o tratamento de $\mathrm{pH}$ original igual a 6,0 proporcionou a partir dos 9DAI o maior número de raízes por planta (Figura $1 \mathrm{~A}$ ) e que foi nesse tratamento que foram constatadas as maiores alterações de $\mathrm{pH}$, já a partir dos 6DAI (Figura 1F), sugere-se que houve uma participação marcante do processo de absorção de nutrientes pelas raízes nestas alterações. Observações nesse sentido foram relatadas por vários autores (LEIFERT et al., 1992; LEIFERT et al., 1995). Tem sido observado que o cultivo de tecidos in vitro reduz o $\mathrm{pH}$ do meio de cultivo $\mathrm{MS}$, o qual apresenta baixa capacidade de tamponamento (LEIFERT et al., 1995). A acidificação da rizosfera de plantas in vivo ou in vitro é dependente da liberação de ácidos orgânicos ou prótons durante a absorção, principalmente, do N-NH ${ }^{+}$(MARSCHNER, 1995; MORARD \& HENRY, 1998).

Em conclusão, valores de $\mathrm{pH}$ do meio de cultivo MS próximos a 6,0, ajustados antes da autoclavagem, são ideais para o crescimento da $\boldsymbol{P}$. glomerata cultivada in vitro. Além disso, destaca-se que o crescimento das plântulas modificaram significativamente o $\mathrm{pH}$ inicial do meio de cultivo.

\section{REFERÊNCIAS}

LEIFERT, C. et al. Effect of medium acidity on growth and rooting of different plants growing in vitro. Plant Cell, Tissue and Organ Culture, Netherlands, v.30, p.171-179, 1992.

LEIFERT, C. et al. Mineral and carbohydrate nutrition of plant cell and tissue cultures. Critical Reviews in Plant Sciences, Boca Raton, v.14, n.2, p.83-109, 1995.

MARSCHNER, H. Mineral nutrition of higher plants. San Diego: Academic, 1995. 889p.

MORARD, P.; HENRY, M. Optimization of the mineral composition of in vitro culture media. Journal of Plant Nutrition, New York, v.21, n.8, p.1565-1576, 1998.

MONTANARI JÚNIOR, I. Aspectos do cultivo comercial do ginseng brasileiro (Pfaffia glomerata (Spreng) Pedersen). São Paulo: CPQBA-UNICAMP, 1999. 3p. (Boletim Agroecológico, 12).

MURASHIGE, T.; SKOOG, F. A revised medium for rapid growth and bioassays with tobacco tissue cultures. Physiologia Plantarum, Copenhagen, v.15, p.473-497, 1962.

NICOLOSO, F.T. et al. Micropropagação do ginseng brasileiro [Pfaffia glomerata (Spreng.) Pedersen]. Revista Brasileira de Plantas Medicinais, Botucatu, v.3, n.2, p.11-18, 2001.

SKIRVIN, R.M. et al. Stability of tissue culture medium $\mathrm{pH}$ as a function of autoclaving, time, and cultured plant material. Plant Cell Reports, Heidelberger, v.5, p.292-294, 1986. 